\title{
Analysis Of Students' Critical Thinking and Independence of Learning Through Problem-Based Learning
}

\author{
Erinda Titik Rizki Fani, Baiduri, Alfiani Athma Putri Rosyadi \\ Study Program of Mathematics Education, Faculty of Teacher Training and Education \\ University of Muhammadiyah Malang \\ erindatitik@yahoo.co.id
}

\begin{abstract}
The purpose of this research was to describe the VIIIF students' critical thinking and independence of learning through problem-based learning. The type of this research was qualitative descriptive supported quantitative data with 30 VIII F students as the subject.This study was conducted for four times meetings. The data were taken by using observation sheet of their critical thinking and questionnaire of their independence of learning. The result of data obtained in form of observations and questionnaires which then descriptive analysis. The result showed that their critical thinking on the aspect of giving explanation, concluding, set the strategy and tactics of the categories as good and very good, while their independence of learning on the aspect of self-confidence, initiative, and responsibility were independent.
\end{abstract}

Keywords: Critical Thinking, Students' Independence of Learning, Problem-Based Learning

\section{INTRODUCTION}

Critical thinking is one of the most important things that learners should have. That is because by having the ability of critical thinking can help learners in thinking rationally in overcoming the problems being faced and looking for alternative solutions of them. According to Cahyo (2013), low critical thinking is caused by several factors which one of them is learning model implemented by the teacher is not really appropriate in conveying materials and objectives of learning process and improvingtheir mathematical critical thinking skills. That factor also causes them difficult to develop their independence of learning because itis an important thing that needs to be improved in order to support the success of students in learning (Abdullah et al, 2015).

Based on observations that do by researchers at SMPN 3 Singosari, it was still found the problems of VIII F students. The problems is fairly prominent from the student critical thinking and independence is learning that is still lacking. Besides, the low critical thinking ability can also be seen from the average score of first ability of SMP ArRahman Percut students which was only 68 on a scale of $0-100$, this score is categorized as enough.In addition, a phenomenon that occurs regarding low independence of learning also happened in SMPN 27 Purworejo that the students did not pay attention to the explanation of teachersat the time of learning process. From the findings of the research,their independence of learning is still less than $70 \%$ of $100 \%$ (Jumaisyaroh, 2014; Kurniawati, 2010).

Realizing the importance of the students' mathematical critical thinking and independence of learning which needs a strategy and learning approach that can involves 
them actively in the learning processmore.Teacher needs to choose an appropriate learning model to achieve good students' critical thinking andindependence of learning in which one of them by applying problem-based learning.

\section{RESEARCH METHODS}

The type of research used was descriptive. It described the process of students' critical thinking and independence of learning through Problem-Based Learning.The approach used in this study is a qualitative supported quantitative data. It means that this research used descriptive statistics such as average percentage. SMPN 3 Singosari was chosen. It was conducted on March 20 to 29, 2017 with 30 VIII-F even semester students as the subject and the object wastheir critical thinking and independence of learning. While instruments used in Critical Thinking Observation Sheet and Questionnaire. Technique of data analysis was doneby using descriptive statistics include average percentage.

\section{RESULTS AND DISCUSSION}

Critical thinking on learning mathematics through problem-based learning was assessed by using a sheet of observasi performed by three observers. The assessment of critical thinking data which further analyzed. The observations obtained namely as follows:

Table 1 Percentage of Students' Critical Thinking

\begin{tabular}{|c|c|c|c|c|c|}
\hline \multirow[t]{2}{*}{ No. } & \multirow[t]{2}{*}{ Indicator } & \multicolumn{4}{|c|}{ Percentage of Meetings } \\
\hline & & 1 & 2 & 3 & 4 \\
\hline \multicolumn{6}{|c|}{ Giving Explanation } \\
\hline 1 & $\begin{array}{l}\text { Students are able to define their } \\
\text { understanding by asking or } \\
\text { answering questions. }\end{array}$ & $77,7 \%$ & $75,5 \%$ & $77,7 \%$ & $74,4 \%$ \\
\hline 2 & $\begin{array}{l}\text { Students can create an argument } \\
\text { based on the data. }\end{array}$ & $75,6 \%$ & $84 \%$ & $82,2 \%$ & $82,5 \%$ \\
\hline & Average & $\begin{array}{l}76,6 \% \\
\text { (B) }\end{array}$ & $\begin{array}{l}79.7 \% \\
\text { (B) }\end{array}$ & $\begin{array}{l}79,9 \% \\
\text { (B) }\end{array}$ & $\begin{array}{l}78,4 \% \\
\text { (B) }\end{array}$ \\
\hline \multicolumn{6}{|c|}{ Concluding } \\
\hline 3 & $\begin{array}{l}\text { Students are able to make } \\
\text { conclusion based on the statements, } \\
\text { results of analysis, and logic form } \\
\text { new findings. }\end{array}$ & $78,1 \%$ & $71,1 \%$ & $74 \%$ & $73,3 \%$ \\
\hline 4 & $\begin{array}{l}\text { Students give solution of the } \\
\text { problem. }\end{array}$ & $76,6 \%$ & $80,3 \%$ & $74,8 \%$ & $77 \%$ \\
\hline & Average & $\begin{array}{l}77,3 \% \\
\text { (B) }\end{array}$ & $\begin{array}{l}75,7 \% \\
(\mathrm{~B})\end{array}$ & $\begin{array}{l}74,4 \% \\
\text { (B) }\end{array}$ & $\begin{array}{l}75,1 \% \\
\text { (B) }\end{array}$ \\
\hline \multicolumn{6}{|c|}{ Arranging Strategy and Tactics } \\
\hline 5 & $\begin{array}{l}\text { Students are able to interact with } \\
\text { other friends. }\end{array}$ & $82,2 \%$ & $80,3 \%$ & $77,7 \%$ & $77,7 \%$ \\
\hline 6 & $\begin{array}{l}\text { Students are able to determine } \\
\text { action in learning process. }\end{array}$ & $77,4 \%$ & $81,4 \%$ & $80,7 \%$ & $81,8 \%$ \\
\hline & Average & $\begin{array}{l}79,8 \% \\
\text { (B) }\end{array}$ & $\begin{array}{l}80,8 \% \\
(\mathrm{SB})\end{array}$ & $\begin{array}{l}79,2 \% \\
\text { (B) }\end{array}$ & $\begin{array}{l}79,7 \% \\
\text { (B) }\end{array}$ \\
\hline
\end{tabular}


Students' independence of learning mathematics through problem-based learning was assessed by using questionnaire given each meeting after the learning processwas completed.The research obtained data of independence of learning which then analyzed and categorized. The result of the questionnaire obtain was follows:

Table 2 Percentage of Students' Independence of Learning

\begin{tabular}{|c|c|c|c|c|c|c|}
\hline \multirow[t]{2}{*}{ No. } & \multirow[t]{2}{*}{ Indicator } & \multicolumn{4}{|c|}{ Percentage of Meetings } & \multirow[t]{2}{*}{ Category } \\
\hline & & $\mathbf{1}$ & 2 & 3 & 4 & \\
\hline 1 & Confidence & $67,83 \%$ & $76,66 \%$ & $76,67 \%$ & $77,16 \%$ & Independent \\
\hline 2 & Initiative & $71,16 \%$ & $74,83 \%$ & $75 \%$ & $76,33 \%$ & Independent \\
\hline 3 & Responsiblity & 72,33 & $75,66 \%$ & $76 \%$ & $76,16 \%$ & Independent \\
\hline
\end{tabular}

This research was descriptive which aims to find out the students' critical thinking and independence of learning through problem-based learning as the aspect.

From the first to the fourth meeting, itwas achieved both good and excellent criteria in every aspect be observed. Their critical thinking be observed in this study included explaining, concluding, and organizing strategies and tactics.Giving an explanation consisted of two aspects namelybeing able to set their understanding by asking or answering questions and make an argument based on the data. The concluding aspect consisted of two observed aspects namelybeing able to make conclusion from the statement and result of analysis, give solution of the problem. While the aspects of strategy and tactics also consisted of two observed indicators namely being able to interact with other friends and determine the action in learning.

Based on the data, it could beconcluded that critical thinking from VIIIF students of SMPN 3 Singosari increased and decreased.This was proven by every indicator of critical thinking aspects which increased and decreasedalthough every increase and decrease was not too significant and still in the category of good and very good.

Another aspect studied was their independence of learning. It consisted of three observed indicators suchas confidence, initiative, and responsibility.Based on the results of this study, the first indicator, confidence,wasin independent category. The second and the last one,the two initiatives andresponsibility were also in independent category.

Based on the questionnaire results of students' independence of learning through problem-based learning showed that it increased. The three aspects were in independent category. This is in same with previous research conducted by Setianingsih (2013) in SMPN 2 Purwodadi which is for student self-reliance through problem-based learning on the responsibility aspect in cycle I that is 15 students $(39,4 \%)$ and in cycle II that is 25 students $65,79 \%$ independent category) and self confidence aspect in cycle I is 6 students $(15,79 \%)$ and on cycle II that is 13 students $(34,21 \%$ independent category). 


\section{CONCLUSION}

Based on the results of previous discussion, the following conclusions are:

a. Critical thinking of VIIIF students of SMPN 3 Singosari through problem-based learning on the aspects of explaining, concluding, and managing strategies and tactics was in good and very good category.

b. While their independence of learning through problem-based learning on the aspects of confidence, initiative, and responsibility was in independent category.

\section{REFERENCES}

Abdullah, dkk. 2015. Membangun Kemandirian Belajar Sswa Melalui Pembelajaran Matematika Realistik. Jurnal Ilmiah Program Studi Pendidikan Matematika STIKIP Siliwangi Bandung,88-91

Cahyo. A. 2013. Panduan Aplikasi Teori-Teori Belajar Mengajar. Jojakarta: Diva Press melalui Pendekatan Matematika Realistik .Jurnal Pendidikan Matematika volume 4 no 2

Jumaisyaroh,dkk. 2014. Peningkatan Kemampuan Berpikir Kritis Matematis dan Kemandirian Belajar Siswa melalui Pembelajaran Berbasis Masalah. Jurnal Pendidikan Matematika.

Kurniawati, D. 2010. Upaya Meningkatkan Kemandirian Belajar Siswa dalam Pembelajaran Matematika Melalui Model Cooperative Learning Tipe Kepala Bernomor Terstruktur pada Siswa SMP N 2 Sewon Bantul. Skripsi tidak Diterbitkan. Yogyakarta: Universitas Negeri Yogyakarta.

Setianingsih, E. 2013. Peningkatan Kemandirian dan Prestasi Belajar Matematika melalui Strategi Problem Based Learning. Jurnal Pendidikan Matematika. 